\title{
Primary Lymphoma of Bone: A case report and brief review of literature
}

\author{
Mra Aye $^{1 *}$, Jason Cabot ${ }^{2}, Z^{2}$ lkimi Roslly ${ }^{3}$ and Chiew Junloong ${ }^{3}$ \\ ${ }^{1}$ Department of Medicine, Melaka Manipal Medical College, Melaka 75150, Malaysia \\ ${ }^{2}$ Cancer Center of Guam, 633 Gov. Carlos Camacho Rd., B5, Tamuning, Guam 96913, USA \\ ${ }^{3}$ Jasin General Hospital, Jasin 77000, Malaysia
}

\begin{abstract}
Skeletal manifestations of Non-Hodgkin Lymphoma (NHL) is unusual, occurring in less than 5\% of NHL cases; and primary non-Hodgkin lymphoma of bone (PLB) is rare, usually diffuse large B-cell lymphoma. PLB generally presents with localised bone pain, or, less frequently, soft tissue swelling. Pathological fractures, well documented in soft tissue sarcomas, are unusual in PLB. We report a case of polystotic PLB that presented with involvement of left anterior tibia (with pathologic facture) and left frontal skull.
\end{abstract}

\section{Introduction}

Primary Non Hodgkin Lymphoma (NHL) of bone (primary bone lymphoma, PLB) a rare condition, accounting for less than 1-2\% of adult NHL and less than $7-10 \%$ primary bone tumors [1-8], was first described by Oberling [9] in 1928 as reticulum cell sarcoma of bone. This was subsequently recognised as of lymphoid origin and renamed malignant lymphoma of bone [10,11]. Most primary lymphomas of bone are diffuse large B-cell lymphoma (DLBCL) subtype, the majority of cases are limited to bone, and occur in adults aged 45-60 years [15]. PLB may be difficult to diagnosis without a high level of suspicion [8]. Pain without antecedent trauma, unrelieved by rest is the most common presenting symptom $[1,5-8]$. PLB may present as monostotic or polystotic disease [3-8], often in long bones, with a slight male predominance. Bones most commonly involved are femur (29\%), skull (11\%) and tibia (10\%) with variable radiographic manifestations [12].

PBL is rare compared to plasma cell neoplasms in bone, either plasmacytoma or myeloma. As bone marrow is the homing site of plasma cells there is circumstantial evidence that PBL represents post-germinal centre B-cells [13]. Although conventional radiology and other imaging modalities such as bone scan, CT and PET are not specific, MRI appears to be the most sensitive imaging technique for diagnosis of PBL [14-18].

\section{Case}

A 46- year-old man with hypertension, gout, and chronic kidney disease was admitted for increasing painful swelling of anterior left tibia of two months duration causing ambulation difficulties. There was no fever or night sweats but poor appetite and significant weight loss. He had noted an asymptomatic, painless swelling of the left frontal region one year prior, but did not seek medical attention. This swelling subsequently rapidly increased in size, and was accompanied by painful swelling posterior and inferior to the left knee.

Examination revealed a thin, pale, weak, orientated male, with a non-tender soft, fluctuant mass of the left frontal region of skull measuring $8 \times 8 \mathrm{~cm}$, fixed to the bone, a left preauricular lymph node $2 \times 2 \mathrm{~cm}$, firm, and non-tender. There was a $3 \times 3 \mathrm{~cm}$ central mass around the umbilicus which was fixed and non-tender, multiple, bilateral palpable inguinal lymph nodes more prominent on the right, and gross bilateral pedal oedema. There was a swelling at the back of left tibia, about $10 \mathrm{~cm}$ below the knee, measuring $4 \times 4 \mathrm{~cm}$, non-tender to palpation, firm and with normal overlying skin. Two weeks later he developed massive abdominal distension, thought to be ascites, and gross, bilateral leg edema.

Plain X-ray of left knee showed a soft tissue swelling with moth eaten bone erosion of upper tibial posterior aspect with a pathological fracture. Plain X-ray skull revealed large erosive lesion of left frontal bone. Chest X-ray was normal with no rib erosions. Skeletal survey showed no lytic lesions except left frontal bone and tibia.

USG Doppler of legs demonstrated no deep vein thrombosis and USG abdomen, a large lobulated heterogeneously hypoechoic mass in the right lower abdomen measuring $8.4 \times 8.7 \times 13.4 \mathrm{~cm}$ with similar smaller masses around this mass with minimal ascites. Liver, spleen, gall bladder and pancreas were normal and there was renal parenchymal disease.

CT and Contrast Enhanced CT (CECT) of left fibula and tibia revealed lytic bone lesion involving the proximal left tibia with pathological fracture of left proximal tibia posteriorly (Figures 1 and 2), with a soft tissue component measuring $9 \times 10.9 \times 10.5 \mathrm{~cm}$, extending superiorly into the popliteal fossa and erosions noted in distal left femur. CECT brain revealed a large enhancing mass in the left frontal

Correspondence to: Mra Aye, Department of Medicine, Melaka Manipal Medical College, Melaka 75150, Malaysia, Tel: +60-1955-45052; E-mail: mraaye@ hotmail.com

Key words: diffuse large B cell non-hodgkin lymphoma, bone erosion, pathological fracture, primary bone lymphoma, polystotic $P B L$

Received: August 06, 2017; Accepted: August 25, 2017; Published: August 28, 2017 


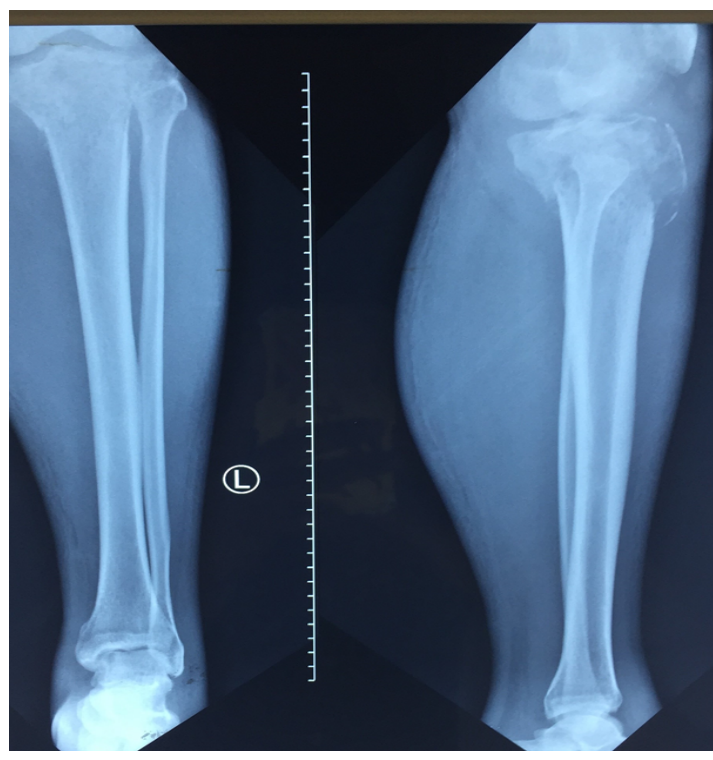

Figure 1. CT of left tibia and fibula.

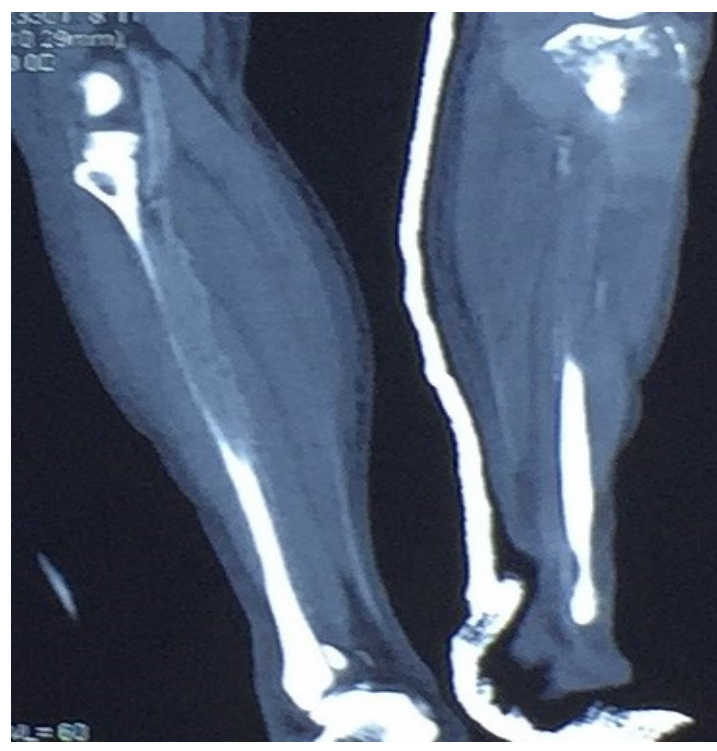

Figure 2. Contrast enhanced CT of left tibia.

region measuring $8.7 \times 6.7 \times 7.8 \mathrm{~cm}$ extending from the scalp to the extradural space (Figure 3 ). There were no focal brain parenchymal lesions and normal grey/white matter differentiation. CT of abdomen and pelvis revealed a large lobulated mass anterior to the lumbar spine extending from the level of $3^{\text {rd }}$ lumbar vertebrae superiorly and down to the right iliac region measuring $13.3 \times 10.9 \times 19.8 \mathrm{~cm}$ (Figure 4), with no clear plane between the mass and right psoas muscle, and encasing the common iliac arteries, right iliac vessels and inferior vena cava and a dilated right ureter traced down to the mass with mild right hydro nephrosis. Multiple enlarged nodes were seen in the left iliac and inguinal regions and lateral to the mass. Features of bilateral renal parenchymal disease were noted and there was minimal ascites.

\section{Urine was negative for light chains.}

Laboratory exams revealed anaemia $\{\mathrm{Hb} 10.3 \mathrm{~g} / \mathrm{L}$ (13-17) $\}$ with normal white blood cells and platelets, ESR was markedly elevated $\{98 \mathrm{~mm} / 1 \mathrm{st} \mathrm{hr}(0-22 \mathrm{~mm})\}$, blood urea $18.4 \mathrm{mmol} / \mathrm{L}$ (3.2-8.2) with creatinine $471 \mathrm{umol} / \mathrm{L}$ (82-115), corrected serum calcium $2.92 \mathrm{mmol} / \mathrm{L}$
(2.16-2.50), uric acid $806 \mathrm{mmol} / \mathrm{L}$ (208.4-428.4). Serum phosphate, magnesium, liver function test and coagulation profile were within normal range.

A Tru Cut biopsy of the tibial mass was performed and the pathological fracture immobilized. Biopsy revealed diffuse large B cell lymphoma, with diffusely positive CD20 and MUM1; and negative CD3, CD10, CD138, BCL6 and CKAE1/AE3. Ki- 67 was $80 \%$.

The patient was referred to the haematology department for further management but expired one month later while receiving chemotherapy.

\section{Discussion}

Originally provisional diagnosis of multi-osseous plasmacytoma was suspected, but changed to aggressive lymphoma when the huge

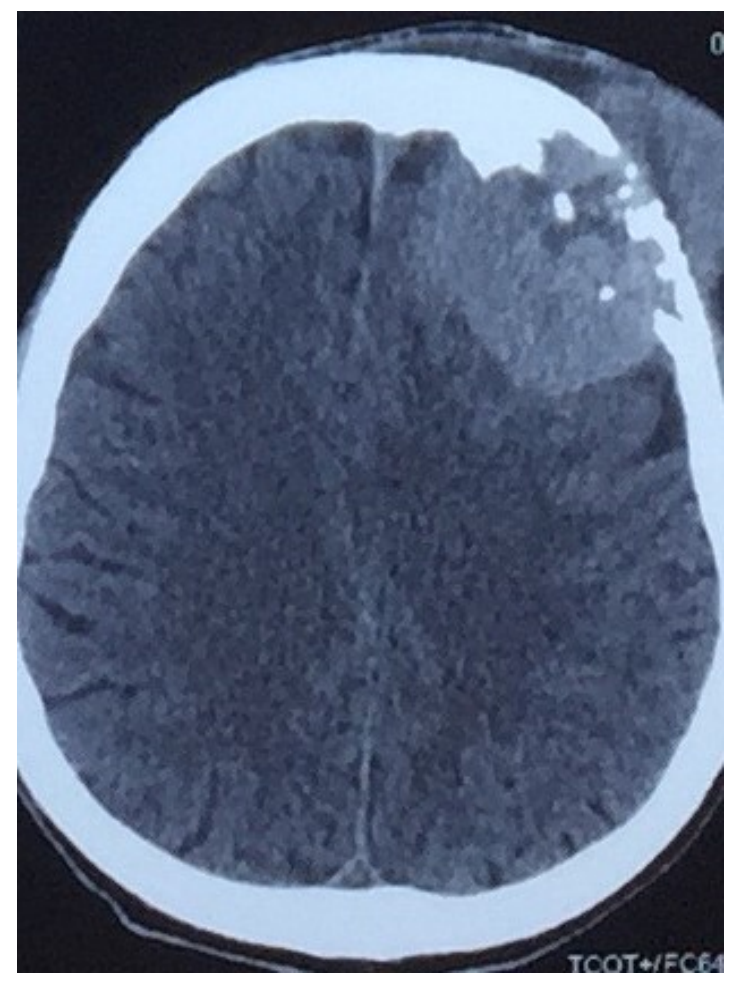

Figure 3. Contrast enhanced CT brain scan.

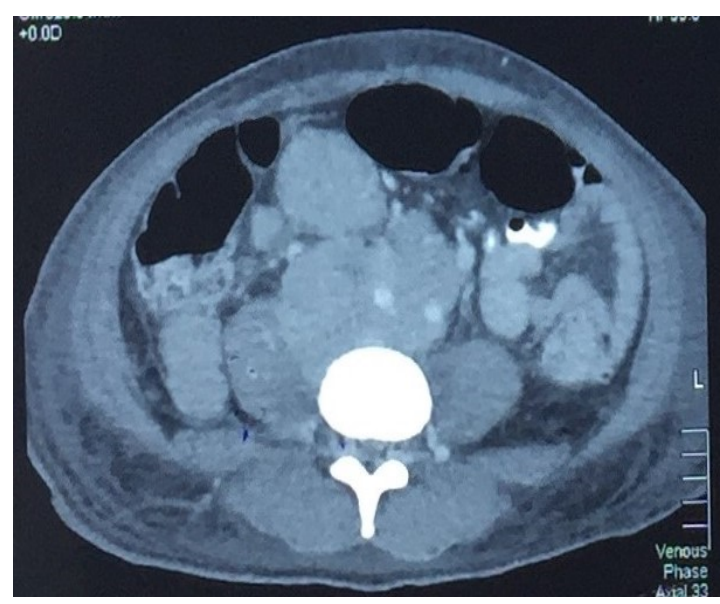

Figure 4. CT abdomen. 
lobulated abdominal mass was seen on abdominal USG. It is felt our patient had PBL and bone involvement as a primary and not secondary event since the disease began in bones, with subsequent pathological fractures, and visceral masses becoming evident only after a time lapse of one year.

Literature review indicates skeletal involvement with NHL is less than $5 \%$, and in all cases, bony involvement followed some time after presentation of the primary lesion [13]. Disseminated NHL presenting with pathological fracture is unusual $[18,19]$. Our patient appeared to have a left frontal swelling at onset, followed some months later by a tibial tumour with fracture, both with osseous erosions. There was also a large retroperitoneal mass which infiltrated widely.

Our case had many attributes of multifocal PBL such as age, painless bone swelling for considerable time without systemic symptoms, diffuse large B cell lymphoma in histology [1-5] and presence of common radiological features of $\mathrm{PBL}$ on CT scan: permeative osteolytic moth eaten lesions in proximal tibia with cortical break and fractures on CECT (contrast enhanced CT) of left tibia [14] (Figures land 2). MRI has specific features of PBL [14-18] but our patient succumbed before the due date of MRI.

Although the original criteria of PBL by Coley [20] described solitary bone involvement, a larger group was described by Ostrowski et al. [21] who classified osseous lymphoma into four groups: Group 1, solitary primary bone lymphoma; Group 2 involving more than one bone without nodal or visceral disease; Groups 3 and 4 with distant nodal or visceral disease. The difficulty with multifocal PBL is distinguishing cases with primary osseous sites and extension (groups 3 and 4), from disseminated NHL and secondary osseous involvement. Multifocal osseous PBL, like solitary PBL, has a predilection for bones about the knee [14]. The combination of radiologic abnormalities of proximal tibia, distal femur, and skull is very uncommon in osseous involvement of disseminated NHL [22]. Overall, multifocal PBL exhibits a significantly better prognosis compared to patients with advanced-stage diffuse large B-cell NHL [23].

\section{Conclusion}

We report a case of diffuse large B cell lymphoma of bone originating in multi-osseous sites. PBL is rare and diagnosis might be delayed or missed if it is not considered. It is reported to have a better prognosis than disseminated lymphoma if treated early and should be in the list of the differential diagnoses of bone swelling with bone fracture.

\section{References}

1. Power DG, McVey GP, Korpanty G, Treacy A, Dervan P, et al. (2008) Primary bone lymphoma: single institution case series. Ir J Med Sci 177: 247-251. [Crossref]

2. Lima FP, Bousquet M, Gomez-Brouchet A, de Paiva GR, Amstalden EM, et al. (2008) Primary diffuse large B-cell lymphoma of bone displays preferential rearrangements of the c-MYC or BCL2 gene. Am J Clin Pathol 129: 723-726. [Crossref]

3. Ramadan KM, Shenkier T, Sehn LH, Gascoyne RD, Connors JM (2007) A clinicopathological retrospective study of 131 patients with primary bone lymphoma: a population-based study of successively treated cohorts from the British Columbia Cancer Agency. Ann Oncol 18: 129-135. [Crossref]
4. Barbieri E, Cammelli S, Mauro F, Perini F, Cazzola A, et al. (2004) Primary nonHodgkin's lymphoma of the bone: treatment and analysis of prognostic factors for Stage I and Stage II. Int J Radiat Oncol Biol Phys 59: 760-764. [Crossref]

5. Stein ME, Kuten A, Gez E, Drumea K, Ben-Shachar M, et al. (2003) Primary lymphoma of bone--a retrospective study. Experience at the Northern Israel Oncology Center (1979-2000). Oncology 64: 322-327. [Crossref]

6. Rappaport DC, Chamberlain DW, Shepherd FA, Hutcheon MA (1998) Lymphoproliferative disorders after lung transplantation: imaging features. Radiology 206: 519-524. [Crossref]

7. Hsieh PP, Tseng HH, Chang ST, Fu TY, Lu CL, et al. (2006) Primary non-Hodgkin's lymphoma of bone: a rare disorder with high frequency of T-cell phenotype in southern Taiwan. Leuk Lymphoma 47: 65-70. [Crossref]

8. Glotzbecker MP, Kersun LS, Choi JK, Wills BP, Schaffer AA, et al. (2006) Primary non-Hodgkin's lymphoma of bone in children. J Bone Joint Surg Am 88: 583-594. [Crossref]

9. Oberling C (1928) Reticulosarcomas and reticulo-endotheliosarcomas of the bone marrow (Ewing's sarcomas). Bull Assoc Fr Etud Cancer 17: 259-296.

10. Boston HC Jr, Dahlin DC, Ivins JC, Cupps RE (1974) Malignant lymphoma (so-called reticulum cell sarcoma) of bone. Cancer 34: 1131-1137. [Crossref]

11. Ivins JC, Dahlin DC (1963) Malignant Lymphoma (Reticulum Cell Sarcoma)? Mayo Clinic Proceedings 38: 375-378.

12. Salter M, Sollaccio RJ, Bernreuter WK, Weppelmann B (1989) Primary lymphoma of the bone: The use of MRI in the pretreatment evaluation. Am J Clin Oncol 12: 101-105. [Crossref]

13. Kitsoulis P, Vlychou M, Papoudou-Bai A, Karatzias G, Charchanti A, et al. (2006) Primary lymphomas of bone. Anticancer Res 26: 325-337. [Crossref]

14. Krishnan A, Shirkhoda A, Tehranzadeh J (1989) Primary lymphoma of the bone. The use of MRI in the treatment evaluation. Am J Clin Oncol 12: 101-105.

15. Haussler MD, Fenstermacher MJ, Hohnston DA, Harle TS (1999) MRI of primary lymphoma of bone: cortical disorder as a criterion for differential diagnsis. J Magn Reson Imag 9: 93-100. [Crossref]

16. Hicks DG, Gokan T, O Keefe RJ, Totterman SM, Fultz PJ, et al. (1995) Primary lymphoma of bone: correlation of magnetic resonance imaging features with cytokine production by tumor cells. Cancer 75: 973-980. [Crossref]

17. Sundaram M, Mc Guire MH (1988) Computed tomography or magnetic resonance for evaluating the solitary tumor or tumor like lesion of bone? Skeletal Radiol 17: 393-401. [Crossref]

18. Siddiqui YS, Khan AQ, Sherwani M (2013) Pathological Fractures in Primary NonHodgkin's Lymphoma of the Bone: A Case Series with Review of the Literature. J Clin Diagn Res 7: 513-517. [Crossref]

19. Ramadan KM, Shenkier T, Sehn LH, Gascoyne RD, Connors JM (2007) A clinicopathological retrospective study on 131 patients with primary bone lymphoma: A population-based study of successively treated cohorts from the British Columbia Cancer Agency. Ann Oncol 18: 129-135. [Crossref]

20. Coley BL, higinbotham NL, groesbeck HP (1950) Primary reticulum-cell sarcoma of bone; summary of 37 cases. Radiology 55: 641-658. [Crossref]

21. Ostrowski ML, Unni KK, Banks PM, Shives TC, Evans RG, et al. (1986) Malignant lymphoma of bone. Cancer 58: 2646-2655. [Crossref]

22. Melamed JW, Martinez S, Hoffman CJ (1997) Imaging of primary multifocal osseous lymphoma. Skeletal Radiol 26: 35-41. [Crossref]

23. Messina C, Ferreri AJ, Govi S, for the International Extranodal Lymphoma Study Group (I.E.L.S.G.). (2014) Clinical features, management and prognosis of multifocal primary bone lymphoma: a retrospective study of the international extranodal lymphoma study group (the IELSG 14 study). Br J Haematol 164: 834-840. [Crossref]

Copyright: (C2017 Aye M. This is an open-access article distributed under the terms of the Creative Commons Attribution License, which permits unrestricted use, distribution, and reproduction in any medium, provided the original author and source are credited. 